\title{
Insect oil and protein: Biochemistry, food and other uses: Review
}

\author{
Abdalbasit Adam Mariod \\ College of Sciences and Arts-Alkamil, King Abdulaziz University, P.O BOX 110, ALKAMIL 21931 Alkamil, KSA; \\ basitmariod@yahoo.com, aalnadif@kau.edu.sa
}

Received August 2013

\section{ABSTRACT}

In searching for new sources of oil, protein and gelatin researchers have investigated many wild plants, but our research group took a different approach: We looked at insects as oil, protein and gelatin source for both nutritional and industrial applications. According to Sudanese indigenous knowledge, many insects have food and medicinal uses. We targeted two of these insects for our research: Aspongopus vidiuatus (melon bug) and Agonoscelis pubescens (sorghum bug). The two insects showed $27.0 \%$ and $28.2 \%$ crude protein, $45 \%$ and $60 \%$ oil, respectively. The oils contained $46.5 \%$ and $40.9 \%$ oleic acid, $3.4 \%$ and $34.5 \%$ linoleic acid, $44.2 \%$ and 12.1\% palmitic acid and traces of linolenic acid, respectively. The tocopherol content of these oils amounted to 0.3 and $34.0 \mathrm{mg} / 100 \mathrm{~g}$ oil, respectively. The total content of sterols in the two oils was 17 and $450 \mathrm{mg} / 100 \mathrm{~g}$ oil, respectively, whereas $\beta$-sitosterol was determined as the main compound in all oils with about $60 \%$ of the total sterol. The oxidative stability of the oils, as measured by the Rancimat test at $120^{\circ} \mathrm{C}$, was 38 and $5.1 \mathrm{~h}$, respectively. Edible gelatin was extracted from the two insect using hot water and mild acid and distilled water. SDS-PAGE patterns of the insect gelatins had very low molecular weight chains, and the two gelatins contained $40 \mathrm{kDa}$ as main component, differential scanning calorimetry results confirmed the difference between extraction methods concerning the extracted gelatin quality. FTIR spectra of melon and sorghum bug gelatins were similar and the absorption bands were situated in more than 6 bands in melon bug gelatin and only 6 bands in sorghum bug gelatin. Microstructures of the insect gelatin examined with the scanning electron microscope showed that melon bug exhibited the finest gelatin network with very small voids. Melon bug gelatin showed the finer structure with smaller protein strands and voids than sorghum bug gelatin. Ice cream was made by using $0.5 \%$ insect's gelatine and compared with that made using $0.5 \%$ commercial gelatine as stabilizing agent. The properties of the obtained ice cream produced using insects gelatine were found to be acceptable for the panelists, and no significant differences between ice cream made using insect gelatine when compared with that made using commercial gelatine in their general preferences The behavior of the crude Sorghum bug oil during deep-frying of par-fried potatoes was studied with regard to chemical, physical, and sensory parameters, such as the content of FFA, tocopherols, polar compounds, oligomer TG, volatile compounds, oxidative stability, and total oxidation (TOTOX) value. The results showed that the oil was suitable for deep-frying of potatoes. The oxidative stability of sunflower kernel oil was improved by blending with melon bug oil, the oxidative stability in the Rancimat test was improved from $5 \%$ to $68 \%$ compared to the control, with increasing parts of MBO, respectively. The insect oils were transesterified using methanol or ethanol in the presence of sulfuric acid to obtain biodiesel. The obtained insect biodiesel characteristics were studied in accordance with the DIN EN 14214 specifications for biodiesel. It was possible to prepare the methyl and ethyl esters catalyzed by $\mathrm{H}_{2} \mathrm{SO}_{4}$ from the two insect oils.

Keywords: Agonoscelis pubescens; Aspongopus vidiuatus; Insects; Biochemistry; Food; Biodeisel; Melon Bug; Sorghum Bug

\section{INTRODUCTION}

Grasshoppers, caterpillars, beetles, winged termites, bees, wasps and a variety of aquatic insects are used somewhere 
in the world as human food. Beetles, termites, caterpillars, grasshoppers, crickets, bees, maggots and butterflies are considered significant sources of food in Africa, with varying levels of proteins, fat, minerals and vitamins [1].

During the past few years, there has been a new upsurge of interest in insects as food. One factor that may be responsible is an increasing awareness in the western world that insects are traditionally and nutritionally important foods for many non-western cultures (Foliart, 1992). Mariod et al. [2] has reported that insects could be an important source of edible oil, protein, and gelatin, while Zhou and Han [3] mentioned that insect's proteins are of good quality and high digestibility.

Many vegetable oils are consumed directly, or indirectly as ingredients in food, they serve a number of purposes in texture, flavor and flavor base. Oils can be heated and used to cook other foods. Oils suitable for this objective must have a high flash point. Such oils include the major cooking oils-soybean, canola, sunflower, safflower, peanut, cottonseed, etc. Tropical oils, such as coconut, palm, and rice bran oils, are particularly valued in Asian cultures for high temperature cooking, because of their unusually high flash point [4]

(http://www.stonepages.com/news/archives/001708.html).

According to their indigenous knowledge, Sudanese used many insects as food and medicine. In searching for new sources of oils, our research group has investigated two insects: Aspongopus vidiuatus (Malone bug) and Agonoscelis pubescens (sorghum bug). The group focused on insects as an oil source for both nutritional and industrial applications [5].

The melon bug is an insect belonging to family Pentatomidae, is about $20 \mathrm{~mm}$ long. It is found in most African countries, where it causes damage to watermelon and other cucurbit shoots. The adult bugs can usually be found by lifting the young melon plants from the ground and inspecting the undersides of the leaves. The nymphs pierce the leaves, stems, and young fruits and suck the sap, resulting in wilting, fruit drop, and the death of the plant can be collected in infested fields [6].

The sorghum bug commonly known in Sudan as Dura andat is belong to family Pentatomidae, shield-shaped, about 11 - $13 \mathrm{~mm}$ long, and 6 - $7 \mathrm{~mm}$ wide. Both the upper- and undersides of its body are covered with a fine silvery pubescence after which it is named (Agonoscelis pubescens). In Sudan, the adults infest sorghum during the plant's milky stage. In some areas of Sudan, the collected bugs are pressed, and the expressed oil is used for cooking and some medicinal purposes [7].

\section{BIOCHEMISTRY OF INSECT OIL}

\subsection{Fatty Acids}

Edible oils are of nutritional value since they contain appreciable amounts of the essential fatty acids. Oils extracted from plants have been used since ancient times and in many cultures. Mariod et al. [7] exclusively investigated the oil from melon and sorghum bugs for their oil content and fatty acids. The oil content of melon and sorghum bugs was very high which was amounted to $45 \%$ and $60 \%$ (dry matter), respectively. The major fatty acids of the two oils were palmitic, stearic, oleic and linoleic acids. Compared with oils from cottonseed, peanut, sesame and sunflower seeds insect oils showed similar amounts of saturated and unsaturated fatty acids.

The fatty acid composition determined by gas chromatography in A. viduatus and A. pubescens oils is oleic (45.53\% and $41.15 \%)$, linoleic (4.90\% and $35.21 \%)$ and palmitic (31.33\% and $11.41 \%$ ) acid, with $37.9 \%$ and $20.5 \%$ of saturated fatty acids, respectively [2]. For instance the amounts of saturated and unsaturated fatty acids they contain are comparable with those of oils commonly used in Sudan, such as sesame, groundnut, sunflower, and cottonseed [8].

Aspongubus viduatus and $A$. pubescens have $37.9 \%$ and $20.5 \%$ of saturated fatty acids (SFA), $56.8 \%$ and $43.0 \%$ of monounsaturated fatty acids and $5.3 \%$ and $36.5 \%$ of polyunsaturated fatty acids (PUFA), respectively. The balanced ingestion of foods containing PUFAs reduces cardiovascular disorders. The PUFA: SFA ratio in the oil of $A$. viduatus is relatively lower (about 0.14 ), while it is relatively high (about 1.78 ) in the case of $A$. pubescens. This ratio is recommended to be 0.45 for a healthy diet; so $A$. viduatus oil seems to be healthier than that of $A$. pubescens. In addition, the two insect oils have a n-6/n-3 fatty acids ratio (10.8 and 27.5 for $A$. viduatus and $A$. pubescens, respectively) that should be smaller than 4.0 as suggested by the UK Department of Health [2].

The low amounts of polyunsaturated fatty acids such as linoleic and linolenic acid in insect oils give them high oxidative stability. The fatty acid composition has a much higher influence on the stability of these oils than the minor components of antioxidants present in the oil.

Blending sunflower oil with melon bug oil resulted in an increase of oleic and a decrease of linoleic acid and improved the oxidative stability of sunflower oil. This stability increased with an increase of the percentage of melon bug oil in blends [9]. When melon and sorghum bug oils stored at $30^{\circ} \mathrm{C} \pm 2{ }^{\circ} \mathrm{C}$ in the dark for 24 months, their fatty acid compositions remained almost unaltered. The two oils showed slight changes in their oxidative stability as indicated by the peroxide value (PV), and when this stability was measured by Rancimat method as an induction period, melon bug oil showed a slight decrease with loss of $10 \%$ of its induction period during two years of storage. Sorghum bug oil showed a gradual increase in the PV and a gradual loss of stability as 
measured by induction period IP during storage [9].

No change in the fatty acid composition of insect oils was observed during processing using laboratory refining equipment [10].

\subsection{Tocopherols and Sterols}

The tocopherol content of foods is important to protect food lipids against autoxidation and, thereby to increase their storage life and their value as wholesome foods [11]. Acting as chain-breaking antioxidants, tocopherols react with lipid radicals to convert them into more stable products (Wagner and Elmadfa, 1999). The sorghum bug oil had higher amounts of tocopherol content (Table 1) which was $34.0 \mathrm{mg} / 100 \mathrm{~g}$ while melon bug oil had low amounts of tocopherols about $0.30 \mathrm{mg} / 100 \mathrm{~g}$, respectively.

The amount of sterols (Table 1) in the oils ranged from 17.5 (MBO) to $449.9 \mathrm{mg} / 100 \mathrm{~g}(\mathrm{SBO})$ as general saying the amounts of both tocopherols and sterols of insects oil were lower than most edible oils.

\section{BIOCHEMSITRY OF INSECT PROTEIN}

\subsection{Protein}

The protein concentrations of Aspongubus viduatus and $A$. pubescens were reported to $27.0 \%$ and $28.2 \%$,

Table 1. Tocopherol and Sterol Content (mg/100g oil) of two Insects Oil*.

\begin{tabular}{ccc}
\hline Type of tocopherol & Melon bug oil (MBO) & Sorghum bug oil (SBO) \\
\hline$\alpha-\mathrm{T}$ & 0.17 & 0.88 \\
$\beta$-T & 0.00 & 0.00 \\
$\gamma-\mathrm{T}$ & 0.13 & 32.16 \\
$\mathrm{P} 8$ & 0.00 & 0.21 \\
$\delta$-T & 0.00 & 0.78 \\
Total & 0.30 & 34.03 \\
Type of sterol & & \\
Cholesterol & 1.4 & 2.2 \\
Campesterol & 1.8 & 11.6 \\
Stigmasterol & 0.8 & 25.4 \\
B-sitosterol & 10.6 & 268.8 \\
$\Delta 5$-avenasterol & 0.5 & 16.3 \\
$\Delta 7$-avenasterol & 0.0 & 1.6 \\
$\Delta 7$-stigmasterol & 0.9 & 2.8 \\
$*$ Others & 1.5 & 121.2 \\
Total & 17.5 & 449.9
\end{tabular}

*Data are means of triplicate results. * Others include 24-methylcholesterol, campestanol, chlerosterol, sitostanol, 5,24-stigmastadienol. Source: redesigned from Mariod et al. [12]. respectively, on a dry-matter basis). The total amino acids were 360.5 and $268.8 \mathrm{mg} / \mathrm{g}$ crude protein, respectively, which was less than the $864.2 \mathrm{mg} / \mathrm{g}$ crude protein in chicken egg that is considered as a main protein source in the human diet [2].

\subsection{Gelatin}

Gelatine is a product obtained by the partial hydrolysis of collagen derived from the skin, white connective tissue and bones of animals. It is a gelling protein, which has widely been applied in the food and pharmaceutical industries. Most of commercial gelatine (95\%) is made from hide of porcine and bovine and the remaining part (5\%) comes from bones of porcine and bovine [13]. The study of gelatine from fish by-products, such as skin and bone (Gudmundsson, 2002) and from insects of melon and sorghum bugs [14] has increased for the replacement of mammalian resources.

Gelatin was extracted from the dried adult insects using hot, distilled water and mild acid. Extraction of insect gelatin using hot water gave high yield (3.0\%) followed by mild acid and distilled water (2.5\% and $0.66 \%)$ extraction, respectively. SDS-PAGE pattern showed low molecular weight chains, and the two gelatins contained protein with molecular weight of $40 \mathrm{kDa}$ as main component. The differential scanning calorimetry thermograms results confirm no difference between extraction methods concerning the extracted gelatin quality. FTIR spectra of melon and sorghum bug gelatins were similar and the absorption bands were situated in more than 6 bands in melon bug gelatin and only 6 bands in sorghum bug gelatin. Amide II bands of gelatins from both melon and sorghum bug appeared at around $1554 \mathrm{~cm}^{-1}$, while Amide I bands (1734 - $1632 \mathrm{~cm}^{-1}$ ) appeared only in melon bug method 2 (MB2) and melon bug method3 (MB3) [14].

Microstructures of the insect gelatin examined with the scanning electron microscope showed that melon bug exhibited the finest gelatin network with very small voids. Melon bug gelatin showed finer structure with smaller protein strands and voids than sorghum bug gelatin [14].

\section{FOOD USES OF INSECTS}

In Mexico about seventy eight edible insect species are used as food, the nutrient composition of these species were reported and the protein content was found ranging from $15 \%$ to $81 \%$, fat content from $4.2 \%$ to $77.2 \%$, with carbohydrates up to $77.7 \%$ on a dry-matter basis [15]

Seventeen species of edible insects representing nine families were analyzed for their nutrient composition. These insect species constitute a significant component of diet among the people of southwestern Nigeria [16]. These insects were found contained high crude protein 
(27\% - 30\%). In Thailand, over 50 species of insects are edible and can be consumed throughout the year; these include silk worm pupae, bamboo caterpillars, locusts, beetles and crickets [17].

Mariod et al. [9] improved the oxidative stability of sunflower kernel oil by blending with 10\%, 20\%, 30\% and $40 \%$ of melon bug oil, respectively. The improved oil showed good performance, color and flavor. The same author in the same year reported that sorghum and melon bug oils were suitable for deep-frying only for 6 to $12 \mathrm{~h}$. After that, the oil and the potatoes fried in it did not meet the requirements with regard to the sensory assessment or chemical parameters [18].

Crude melon and sorghum bugs oil were refined using a laboratory refining experiments their phosphatide, peroxide, tocopherol, and sterol contents as well as oxidative stability fell during refining process, while their free fatty acids were almost totally removed. The amounts of total volatiles as well as the amounts of hexanal were decreased during the different processing steps. The color decreased throughout the processing steps up to bleaching, then in the deodorization step it darkened sharply in all samples. No change in the fatty acid composition was observed [10].

\section{INDUSTRIAL USES OF INSECT OIL}

Melon and sorghum bugs oils were transesterified using methanol and ethanol in the presence of sulfuric acid. The resultant fatty acid esters were compared with the DIN 51606 specifications for biodiesel. Most of the insect oil biodiesel characteristics met the DIN specifications (water content, iodine number, phosphorus). However, the kinematic viscosity values of all samples were much higher than those for biodiesel standards. These can be reduced by blending with other low-viscosity biodiesels [19].

\section{REFERENCES}

[1] Womeni, H.M., Linder, M., Tiencheu, B., Mbiapo, F.T., Villeneuve, P., Fanni, J. and Parmentier, M. (2009) Oils of insects and larvae consumed in Africa: Potential sources of polyunsaturated fatty acids. Journal of Oleo Science, 16, 230-235.

[2] Mariod, A.A., Bushra, M., Abdel-Wahab, S.I., Ibrahim, S. and Ain, N.M. (2011) Proximate, amino acid, fatty acid and mineral composition of two Sudanese edible insects International Journal of Tropical Insect, 31, 145-153

[3] Zhou, J. and Han, D. (2006) Proximate, amino acid and mineral composition of pupae of the silkworm Antheraea pernyi in China. Journal of Food Composition and Analysis, 19, 850-853. http://dx.doi.org/10.1016/j.jfca.2006.04.008

[4] Archaeo News (2006) 4000-year-old "kitchen" unearthed in Indiana.

http://www.stonepages.com/news/archives/001708.html

[5] Mariod, A.A. (2011) Insects: New source of oil nutritional and industrial applications. INFORM, 22, 261-320.

[6] Bashir, Y.G.A., Ali, M.K. and Ali, K.M. (2002) IPM options for the control of field watermelon pests in Western Sudan. The 67th Meeting of the Pests and Diseases Committee, Agricultural Research Corporation, ARC, July 2002, Medani, Sudan.

[7] Mariod, A.A., Matthäus, B. and Eichner, K. (2004) Fatty acid, tocopherol and sterol composition as well as oxidative stability of three unusual Sudanese oils. Journal of Food Lipids, 11, 179-189. http://dx.doi.org/10.1111/j.1745-4522.2004.01131.x

[8] Mariod, A.A., Matthäus, B., Eichner, K. and Hussein, I.H. (2009) Study of fatty acids, tocopherol, sterols, phenolic compounds and oxidative stability of three unconventional oils in comparison with four conventional ones. Arab Journal for Food \& Nutrition, 23, 50-55.

[9] Mariod, A.A., Matthäus, B., Eichner, K. and Hussein, I.H. (2005) Improving the oxidative stability of sunflower oil by blending with Sclerocarya birrea and Aspongopus viduatus oils. Journal of Food Lipids, 12, 150-158. http://dx.doi.org/10.1111/j.1745-4522.2005.00013.x

[10] Mariod, A.A., Matthäus, B., Eichner, K. and Hussein, I.H. (2006) Effects of processing steps on the quality and stability of three unconventional Sudanese oils. European Journal of Lipid Science and Technology, 108, 298-308. http://dx.doi.org/10.1002/ejlt.200500323

[11] Kamal-Eldin, A. and L. Appelqvist (1996) The chemistry and antioxidant properties of tocopherols and tocotrienols. Lipids, 31, 671-701. http://dx.doi.org/10.1007/BF02522884

[12] Mariod, A.A., Matthäus, B., Eichner, K. and Hussein, I.H. (2007) Fatty acids composition, oxidative stability and transesterification of lipids recovered from melon and sorghum bugs. Sudan Journal of Science and Technology, 8, 16-20.

[13] Cho, S.M., Kwak, K.S., Park, D.C., Gu, Y.S., Ji, C.I., Jang, D.H., Lee, Y.B. and Kim, S.B. (2005) Processing optimization and functional properties of gelatine from shark (Isurus oxyrinchus) cartilage. Food Hydrocolloids, 18, 573-579. http://dx.doi.org/10.1016/j.foodhyd.2003.10.001

[14] Mariod, A. A., Abdel- Wahab, S.I., Ibrahim, M.Y., Mohan, S., Abd Elgadir, M. and Ain, N.M. (2011) Preparation and characterisation of gelatin from two Sudanese edible insects. Journal Food Science \& Engineering, 1, 45-55

[15] Ramos-Elorduy, J., Moreno J.M.P., Prado, E.E., Perez, M. A., Otero, J.L. and De Guevara, O.L. (1997) Nutritional value of edible insects from the State of Oaxaca, Mexico. Journal of Food Composition and Analysis, 10, 142-157. http://dx.doi.org/10.1006/jfca.1997.0530

[16] Banjo, A.D., Lawall, O.A. and Songonuga, E.A. (2006) The nutritional value of fourteen species of edible insects in southwestern Nigeria. African Journal of Biotechnology, 5, 298-301.

[17] Yhoung-Aree, A.J., Puwastien, P. and Attig, G.A. (1997) 
Edible insects in Thailand: An unconventional protein source. Ecology of Food and Nutrition, 36, 133-149. http://dx.doi.org/10.1080/03670244.1997.9991511

[18] Mariod, A.A., Matthäus, B., Eichner, K. and Hussein, I.H. (2006) Frying quality and oxidative stability of two unconventional oils. Journal of the American Oil Chemists'
Society, 83, 529-538.

http://dx.doi.org/10.1007/s11746-006-1236-5

[19] Mariod, A.A., Klupsch, S., Hussein, I.H. and Ondruschka, B. (2006) Synthesis of alkyl esters from three unconventional Sudanese oils for the use as biodiesel. Energy Fuels, 20, 2249-2252. http://dx.doi.org/10.1021/ef060039a 